\title{
Evaluation on the Implementation of the Round Robin Scheme in the Secondary Schools of Division of Pasay
}

\author{
Dr. Maripaz T. Mendoza \\ Schools Division of Pasay City, Department of Education \\ Philippines \\ DOI: 10.29322/IJSRP.11.08.2021.p11656 \\ http://dx.doi.org/10.29322/IJSRP.11.08.2021.p11656
}

\begin{abstract}
One of the prominent features of $K$ to 12 Curriculum is ensuring unified and seamless learning. This is done with the introduction of spiral progression and horizontal articulation. The Round Robin Scheme schedule was practiced in the Secondary Schools in the division where teachers handle subjects which are of their specialization or which they have mastered through the length of time teaching the subject to address teachers' concern on the content of teaching and learning. This research sought to find out the perceptions of both teachers and learners through a questionnaire and a focus group discussion form the administrators. The research revealed that the scheme implemented has a very positive impact on the content, pedagogy, and assessment of learners, the lessons were applied to situations and contexts common to everyday experience, the lessons helped learners construct meaningful learning experiences, allows use of classroom activities to a very great extent which help learners learn easily, ensured that learners collaborate and share ideas among each other, ensured that evaluation takes place in the context of meaningful activities, allows the use of different ways to evaluate learning outcomes. Impact of the round robin scheme compared to that of the teach all scheme will be a good option for succeeding research.
\end{abstract}

\section{Index Terms}

round robin scheme, $k$-12 implementation, science teaching, horizontal articulation, teacher schedule

\section{INTRODUCTION}

Philippine science education has faced several challenges over the years. In the recent results of the TIMMS 2019, the Philippines scored low that the reliability cannot be ascertained. This challenge has raised all of the education's senses and drive that brings forth important changes with which we adopt.

In May 2013, Pres. Benigno Aquino signed into law RA 10533 known as the Enhanced Basic Education Curriculum ( $\mathrm{K}$ to 12 Program) and implemented in all public and private schools in the country. The program has been adopted not only in schools in the Philippines, but also in Filipino schools abroad

This publication is licensed under Creative Commons Attribution CC BY.

http://dx.doi.org/10.29322/IJSRP.11.08.2021.p11656 that follow the department's curriculum. The K-12 Basic Education Program aims to provide Filipino children with the education they need to compete in a global context.

Orleans (2007) noted that the poor student achievement has prompted educational implementers to constantly identify factors that cause such low achievement and encourage in depth studies. Research reveals that some factors of poor performance include inside and outside the classroom. Internal factors affecting including teaching scheme, and curricula among others have been thought to be the most important component of the science teaching learning process. Further, researchers found that teacher quality appears to be the most important factor affecting student achievement. This includes but not limited to teacher preparedness, certification, and experience forms part of these factors (p. 2)

During implementation of the $\mathrm{K}$ to 12 Program, Science education is greatly affected in the sense that the curriculum must shift from discipline-based to interdisciplinary approach. Teachers had to teach all disciplines of science in every grade level as compared to discipline based wherein a certain domain is taught in each grade level. With this feature, Science Teachers must teach subjects which are not within their specialization.

As cited by Jones (2009) interdisciplinary approach is defined as the commingling of two or more disciplines. It is where two or more subject matters are taught in a manner that perfectly marries each other to reach a common goal or competency. In the context of science teaching, there are four different science specializations taught in one school year.

One of the prominent features of $\mathrm{K}$ to 12 Curriculum is ensuring unified and seamless learning. This is done with the introduction of spiral progression wherein students first learn the basic concepts while they will study the complex ones in the next grade levels. This lets them learn topics and lessons that match their developmental and cognitive skills. As they revisit and share them over again, they strengthen retention and enhance mastery of topics and skills.

In this context, in 2015, the Round Robin Scheme schedule was practiced in the Secondary Schools in the division. In this scheme, teachers handle subjects which are of their specialization or which they have mastered through the 
length of time teaching the subject. Since the Science Education Curriculum follows an interdisciplinary approach, teachers have to teach in all grade levels.

In the study conducted by Folaranmi (2019), the students increased in achievement in chemistry when the round robin scheme was implemented in teaching. Also, in the study of Kim (2017), the science class applying round robin strategy showed significant effect on improving scientific communicative competence and science learning motivation and academic achievement of elementary students.

The Round-Robin scheme was implemented to address teachers' concern on the content of teaching and learning. And it is the intention of this research, to evaluate the Round Robin Scheme being implemented in the Secondary Schools.

\section{RESEARCH LITERATURE}

The advent of the K-12 curriculum implementation in the Philippines, made an impact on the science teaching in Junior High Schools. The conventional approach of having one science discipline taught from the first quarter to the fourth quarter has been challenged by the interdisciplinary approach of teaching science under the K-12 curriculum. By this, teachers have to teach different science subjects from one quarter to another. For example, a particular grade level in junior high school, learners have to be taught chemistry, physics, earth science and biology, one subject for each quarter. This is very much different prior to the K-12 implementation that learners for grade 8 are only taught biology for the entire school year.

Having to address the key feature of this curriculum among others the horizontal articulation and the disciplinary approach, in Samal (2018) this horizontal articulation is the integration of different skills and knowledge across different disciplines. This is essential in achieving the goal of life-long learning. This articulation aligns and collaborates teachers across grading periods within the grade level.

In the context of the current study, and in consonance with the horizontal articulation of the science subject, it was ideally right that the same teacher will teach the science subject in one level for the four grading period or quarters. To strictly adhere to this, the content taught across different science subjects in one year level is believed to be greatly compromised because of the fact that the teachers may not be competent enough to teach different science subjects. In the National Science Education Standards laid down the 5 basic assumptions in science teaching:

1. "The vision of science education described by the Standards requires changes throughout the entire system.

2. What students learn is greatly influenced by how they are taught.

3. The actions of teachers are deeply influenced by their perceptions of science as an enterprise and as a subject to be taught and learned.

This publication is licensed under Creative Commons Attribution CC BY.

http://dx.doi.org/10.29322/IJSRP.11.08.2021.p11656
4. Student understanding is actively constructed through individual and social processes.

5. Actions of teachers are deeply influenced by their understanding of and relationships with students."

These assumptions laid greatly implies that teachers are key players in science education. Specifically, when students learn science basically on how they are taught in class. Ideally, teachers must have theoretical and practical knowledge and also the abilities about teaching and learning science. Not all science teachers can teach any science subject. A biology teacher is very competent in teaching biology and not in teaching physics. It is best to consider the specializations of teachers handling different science subjects as they teach.

In Hobbs (2020), teaching science out-of-field, that is teaching beyond the teacher specialization acquired, raises a number of challenges for teachers. In Nixon (2017), teaching out-of-field has been shown to have negative effects on instruction as well as constrains the development of the teachers. Nixon (2017) further cited that out-of-field teaching occurs when a teacher is assigned to teach a subject for which he or she has not been prepared.

Among these challenges teachers must re-equip themselves with the teaching content in order to be able to deliver the correct science concept to the students and develop their scientific skills. Teachers also are also challenged to develop or adapt engaging and classroom worthy activities in order to affect learning and achieve curricular goals and competencies. Nixon (2017) also cited that when teachers teach out-of-field, they struggle to respond to students' questions in class thus making them spend more time on mastering the content and compromise preparation of engaging activities for better learning experiences. He also cited that together with other researchers, that teachers' instruction was significantly different when teaching the subject in which they were knowledgeable than when teaching a subject in which they were less knowledgeable.

Addressing this issue in the current state of things, the round robin scheduling scheme for science teachers was adapted in the Division of Pasay City. This scheme was adapted to make sure that science teachers can continue teaching the field of their specialization of which they are trained to rather than teaching a different science subject. The round robin scheme that is in effect in the division is as seen below.

Table 1. The Round Robin Scheme Implemented for Junior High School Science Teaching

\begin{tabular}{|c|c|c|c|c|}
\hline \multirow{2}{*}{$\begin{array}{l}\text { GRADE } \\
\text { LEVEL }\end{array}$} & \multicolumn{4}{|c|}{ QUARTER/ GRADING PERIOD } \\
\hline & $\mathbf{1}$ & 2 & 3 & 4 \\
\hline 7 & $\begin{array}{l}\text { Teacher C } \\
\text { (Chemistry) }\end{array}$ & $\begin{array}{l}\text { Teacher B } \\
\text { (Biology) }\end{array}$ & $\begin{array}{l}\text { Teacher D } \\
\text { (Physics) }\end{array}$ & $\begin{array}{l}\text { Teacher A } \\
\text { (Earth } \\
\text { Science) }\end{array}$ \\
\hline 8 & $\begin{array}{l}\text { Teacher D } \\
\text { (Physics) }\end{array}$ & $\begin{array}{l}\text { Teacher A } \\
\text { (Earth } \\
\text { Science) }\end{array}$ & $\begin{array}{l}\text { Teacher C } \\
\text { (Chemistry) }\end{array}$ & $\begin{array}{l}\text { Teacher B } \\
\text { (Biology) }\end{array}$ \\
\hline 9 & $\begin{array}{l}\text { Teacher B } \\
\text { (Biology) }\end{array}$ & $\begin{array}{l}\text { Teacher C } \\
\text { (Chemistry) }\end{array}$ & $\begin{array}{l}\text { Teacher A } \\
\text { (Earth } \\
\text { Science) }\end{array}$ & $\begin{array}{l}\text { Teacher D } \\
\text { (Physics) }\end{array}$ \\
\hline
\end{tabular}




\begin{tabular}{llllll}
\hline 10 & $\begin{array}{l}\text { Teacher A } \\
\text { (Earth } \\
\text { Science) }\end{array}$ & $\begin{array}{l}\text { Teacher D } \\
\text { (Physics) }\end{array}$ & $\begin{array}{l}\text { Teacher D } \\
\text { (Physics) }\end{array}$ & $\begin{array}{l}\text { Teacher C } \\
\text { (Chemistry) }\end{array}$ \\
\hline
\end{tabular}

From the scheme above, science teachers move around from quarter to quarter. Teachers teach only their specialized field to a particular class for a particular quarter. Teacher A for example will be able to teach the Physics subject of different grade levels for one school year.

Teachers in this scheme tend to be more confident in teaching the field of specialization for which they were trained for. They have ample time preparing engaging activities for classroom learning experience as they do not have to focus so much on understanding new concepts to teach.

Students under this scheme of teaching may have varied experiences as new teachers come along every quarter. Students who easily adapt to change may benefit from this scheme. However, other students may respond differently to these changes on teacher and subject matter for every quarter of the school year. This scheme may also be perceived as teacher turn over to a certain extent. In Burnum (2018), students in middle school showed low performance after teachers leave in the middle of the year. However, a significant note was made that some students were not affected much by these changes. These students are among those who are colored and those belonging to the low poverty line.

This round robin scheme or to simply put, the quarterly assignment of science teachers to teach their specialized field can also be seen as a change in schedules of teaching the science subject. Teaching schedules also reveal significant effects to students' learning.

\section{RESEARCH QUESTIONS}

1. What is the perception of the teachers and students with the implementation of the Round Robin Scheme Schedule in terms of a) content; b) pedagogies; c) assessment.

2. What are the reactions of Department Heads and School Heads with the Round Robin Scheme?

\section{RESEARCH METHODOLOGY}

\section{A. Sampling}

The respondents of this research are the selected students and teachers of the Division of Pasay City for the school year 2018-2019. The teachers involved in this research are those that teach the science subject in the regular classes. On the other hand, the students involved in this research are only the Grade 10 students because they have completed the 4year cycle of the round robin scheme. The number of samples taken for this research was computed using Slovin's formula with 5\% margin of error as chosen by the researcher. The teacher respondents will be coming from different Junior High Schools in the city teaching science subjects. The student respondents, the herein learners, are the grade 10 students at the time of conduct of this research based on the above-mentioned reason. These respondents were randomly selected, and they

This publication is licensed under Creative Commons Attribution CC BY.

http://dx.doi.org/10.29322/IJSRP.11.08.2021.p11656 answered the questionnaire designed for this research. The focus group discussion participants of this research are the administrators. All the administrations of the participating schools and purposive non-random sampling was used.

\section{B. Data Collection}

This research collected responses from teachers and learners through a questionnaire and sent through a google form. The questionnaire is composed of 2 parts. The first part is Personal Information of the respondents' details of which is shown below. The second part of the questionnaire are the questions to elicit respondents' perception on the implementation of the Round Robin Scheme. The questions were categories according to Contents, Pedagogies, and Assessment. Each of the questions is answered using a 4-point scale. The questionnaire was answered by the teachers and learners. The second part of the data collection is the conduct of the Focus Group Discussion among the administrators. The FGD was conducted after the administration of the questionnaire.

\section{Data Analysis Plan}

This research will employ a descriptive analysis of the perception of teachers and learners from the results of the questionnaire answered by the respondents. More specifically the weighted means for each of the items from the questionnaire will be taken and compared. Records of high and low results will be analyzed and interpreted to answer the questions set forth in this research. Further, the results of the focus group discussion will be presented as highlights and challenged areas in general. No test of significant difference is aimed in this research.

\section{RESULTS AND DISCUSSION}

What is the perception of the teachers and students with the implementation of the Round Robin Scheme Schedule in terms of: a) content; b) pedagogies; c) assessment.

Table 2. The Perception of Respondents in the Implementation of Round Robin as to Content

\begin{tabular}{ll}
$\begin{array}{l}\text { Perception of Teachers } \\
\text { in the Implementation } \\
\text { of Round Robin }\end{array}$ & \multicolumn{1}{l}{ WEIGHTED MEAN } \\
\cline { 2 - 2 } & TEACHERS
\end{tabular}

\begin{tabular}{|c|c|c|c|c|}
\hline According to Content & & & & \\
\hline 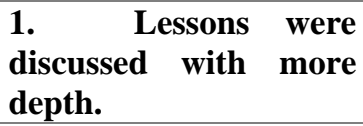 & 3.38 & VGE & 3.25 & VGE \\
\hline $\begin{array}{l}2 . \quad \text { Lessons were } \\
\text { linked between } \\
\text { different areas of } \\
\text { knowledge in the same } \\
\text { subject discipline. }\end{array}$ & 3.41 & VGE & 3.30 & VGE \\
\hline $\begin{array}{l}\text { 3. Difficulties } \\
\text { and misconceptions of }\end{array}$ & 3.28 & VGE & 3.22 & VGE \\
\hline
\end{tabular}


ISSN 2250-3153

lessons were addressed

and able to use

strategies to induce

conceptual change.

$\begin{array}{llllll}\begin{array}{l}\text { 4. Complex } \\ \text { lessons were taught }\end{array} & 3.22 & \text { VGE } & 3.11 & \text { VGE } \\ \text { with ease. }\end{array}$

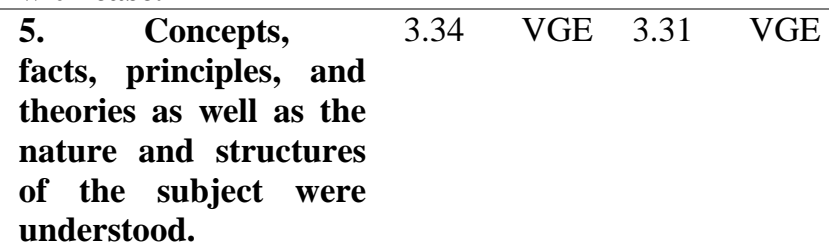

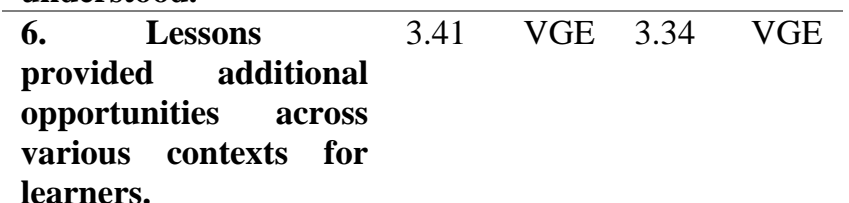

$\begin{array}{llllll}\text { 7. Lessons } & & 3.34 & \text { VGE } & 3.32 & \text { VGE } \\ \text { developed a } \\ \text { understanding } \\ \text { concepts. }\end{array}$

\begin{tabular}{|c|c|c|c|c|}
\hline $\begin{array}{l}\text { 8. Lessons helped } \\
\text { learners to construct } \\
\text { meaningful learning } \\
\text { experiences. }\end{array}$ & 3.28 & VGE & 3.43 & VGE \\
\hline $\begin{array}{l}9 . \text { Lessons were } \\
\text { applied to situations } \\
\text { and contexts common } \\
\text { to } \\
\text { experiences. }\end{array}$ & 3.44 & VGE & 3.29 & VGE \\
\hline $\begin{array}{l}\text { 10. Lessons were } \\
\text { relevant in developing } \\
\text { lifelong skills. }\end{array}$ & 3.47 & VGE & 3.39 & VGE \\
\hline
\end{tabular}

The results reveal that both teachers and learners agree that all items pertaining to the impact of the round robin in terms of the content are evident to a very great extent. This means that the round robin scheme allowed the deeper discussion of the lessons and topics which then developed a deeper understanding among learners. This is primarily because the teachers were able to teach the subject of their specialization or the subject that they were prepared and trained to teach and or have mastered the subject over time. It was also noted that difficulties and misconceptions of lessons were addressed by the scheme and teachers teaching the subject matter were able to use strategies that introduce conceptual. The concepts, facts principals, and theories as well as the nature and structures of the subject were understood fully also because with the confidence and competence of he teachers, the lessons were applied to situation and contexts common to everyday experience which the learners agree that these paved way for the development of lifelong skills. Finally, in the round robin scheme implemented, the horizontal articulation was exemplified because it was seen to a very great extent that lessons were linked between different areas of knowledge in the same subject discipline.

The results in Table 2 shows the weighted means of the teacher and student respondents on each of the 10 item questions under the perception of round robin as to content. It appears that both teachers and students find that all items in the questionnaire were evident to a very great extent.

It is noted from the results of all items that, the lowest of the weighted means recorded was that on items 3 and 4 for both teachers and students. These parallel results show that both teachers and students agree on the lower range of the scale, that using the round robin, the difficulties and misconceptions of lessons were addressed and were able to introduce conceptual change.

On the other hand, it was noted that the teachers recorded a high weighted mean on item 10 which indicates that the round robin scheme can develop lifelong skills. While students had the highest weighted mean on item 8 which indicates that the round robin scheme helps them construct meaningful learning experiences.

The overall weighted mean average under the perception on the implementation of round robin in teaching science according to content was 3.36 and 3.30 for both teachers and students respectively, which implies that both students and teachers agree that the items were exhibited to a very high extent.

Table 3 . The Perception of Respondents in the Implementation of Round Robin as to Pedagogy

\begin{tabular}{|c|c|c|c|}
\hline \multirow{3}{*}{$\begin{array}{l}\text { Perception of Teachers } \\
\text { in the Implementation of } \\
\text { Round Robin } \\
\text { According to Pedagogy }\end{array}$} & \multicolumn{3}{|c|}{ WEIGHTED MEAN } \\
\hline & TEACHERS & \multicolumn{2}{|c|}{ LEARNERS } \\
\hline & & & \\
\hline \begin{tabular}{llr} 
1. Used & \multicolumn{2}{c}{ various } \\
teaching & \multicolumn{2}{c}{ strategies } \\
appropriate & to the \\
objectives & of & the \\
lesson/topic. & &
\end{tabular} & VGE & 3.43 & VGE \\
\hline $\begin{array}{l}2 . \quad \text { Organized } \\
\text { specific examples for } \\
\text { particular topics and } \\
\text { issues. }\end{array}$ & VGE & 3.41 & VGE \\
\hline $\begin{array}{l}\text { 3. Used varied } \\
\text { activities, practical work } \\
\text { and experiments that } \\
\text { are within learners' } \\
\text { interests. }\end{array}$ & VGE & 3.37 & VGE \\
\hline $\begin{array}{l}\text { 4. Delivered the } \\
\text { lessons/topics based on } \\
\text { the diverse interests and } \\
\text { abilities of the learners. }\end{array}$ & VGE & 3.26 & VGE \\
\hline
\end{tabular}




\begin{tabular}{|c|c|c|c|c|}
\hline $\begin{array}{l}5 . \quad \text { Identified } \\
\text { particular techniques to } \\
\text { use in various lessons/ } \\
\text { topics. }\end{array}$ & 3.28 & VGE & 3.35 & VGE \\
\hline $\begin{array}{l}\text { 6. Used classroom } \\
\text { activities which help } \\
\text { learners learn easily. }\end{array}$ & 3.50 & VGE & 3.51 & VGE \\
\hline $\begin{array}{l}\text { 7. Ensured that } \\
\text { classroom participation } \\
\text { and achievement are } \\
\text { encouraged } \\
\text { increased. }\end{array}$ & 3.50 & VGE & 3.40 & VGE \\
\hline $\begin{array}{l}\text { 8. Ensured that } \\
\text { learners collaborate and } \\
\text { share ideas among each } \\
\text { other. }\end{array}$ & 3.56 & VGE & 3.49 & VGE \\
\hline $\begin{array}{l}9 . \quad \text { Encouraged } \\
\text { self-directed and } \\
\text { reflective learning. }\end{array}$ & 3.44 & VGE & 3.43 & VGE \\
\hline $\begin{array}{l}\text { 10. Used varied } \\
\text { activities to encourage } \\
\text { learners to express ideas } \\
\text { freely and improve } \\
\text { further learning. }\end{array}$ & 3.44 & VGE & 3.43 & VGE \\
\hline & 3.46 & VGE & 3.41 & VGE \\
\hline
\end{tabular}

Table 3 presents the results on the perceptions of both the teachers and the learners as to how the implementation of the round robin scheme in teaching science impacts the pedagogy or teaching strategies of the teachers. Results reveal that both the teachers and the learners agree in saying that generally all the items in the questionnaire were evident to a very great extent. As to pedagogy, respondents agree that the scheme paved way for teachers to use varied teaching strategies, engaging activities and experiments which addresses learner's interests and needs. Lessons were delivered to diverse learners which even promote reflective learning. Since teachers do not spend more time to study the content to be taught, they are able to provide substantial learning materials which allows students to learn and understand the lessons very well either alone or in collaboration with others.

The results in Table 3 also shows the weighted means of the teacher and student respondents on each of the 10 item questions under the perception of round robin as to pedagogy. It appears that both teachers and students find that all items in the questionnaire were evident to a very great extent.

From among the weighted means, the lowest recorded by the teacher was 3.28 which pertains to the identification of techniques to use in various lessons or topics. This implies that the round robin scheme may have revealed this item to a very great extent however it was seen on the lower end of the scale. The same is true for the weighted mean of 3.26 , the lowest weighted mean recorded by the students, which is for item number 4 which indicates that lessons are based on diverse interests and abilities of the learners.
On the other hand, the highest weighted mean of 3.56 was recorded from the teacher responses for items indicating that the round robin scheme implementation ensured that learners could collaborate and share ideas among each other. The students however, recorded the highest weighted mean of 3.51 for item number 6 indicating that the round robin scheme implementation in teaching science subjects allows the use of classroom activities which allows them to learn easily.

The overall weighted mean average under the perception on the implementation of round robin in teaching science according to pedagogy was 3.46 and 3.41 for both teachers and students respectively, which implies that both students and teachers agree that the items were exhibited to a very high extent.

Table 4. The Perception of Respondents in the Implementation of Round Robin as to Assessment

\begin{tabular}{|c|c|c|c|c|}
\hline \multirow{2}{*}{$\begin{array}{l}\text { Perception of Teachers in the } \\
\text { Implementation of Round } \\
\text { Robin }\end{array}$} & \multicolumn{4}{|c|}{ WEIGHTED MEAN } \\
\hline & \multicolumn{2}{|c|}{ TEACHERS } & \multicolumn{2}{|c|}{ LEARNERS } \\
\hline \multicolumn{5}{|l|}{ According to Assessment } \\
\hline $\begin{array}{l}\text { 1. Used a variety of } \\
\text { techniques and tools. }\end{array}$ & 3.38 & VGE & 3.29 & VGE \\
\hline $\begin{array}{l}\text { 2. Provided feedback } \\
\text { which allows students to reflect } \\
\text { on progress. }\end{array}$ & 3.38 & VGE & 3.29 & VGE \\
\hline $\begin{array}{l}\text { E. Ensured that } \\
\text { evaluations take place in the } \\
\text { context of meaningful activities. }\end{array}$ & 3.47 & VGE & 3.33 & VGE \\
\hline $\begin{array}{l}\text { 4. Enabled transfer of } \\
\text { knowledge, understanding and } \\
\text { skills successfully into desirable } \\
\text { outputs. }\end{array}$ & 3.41 & VGE & 3.45 & VGE \\
\hline $\begin{array}{l}\text { 5. Used different ways } \\
\text { to evaluate learning outcomes. }\end{array}$ & 3.50 & VGE & 3.46 & VGE \\
\hline $\begin{array}{l}\text { 6. Determined the } \\
\text { existing knowledge and skills of } \\
\text { students. }\end{array}$ & 3.19 & VGE & 3.40 & VGE \\
\hline $\begin{array}{l}\text { 7. Provided } \\
\text { information about difficulties } \\
\text { with a concept. }\end{array}$ & 3.44 & VGE & 3.30 & VGE \\
\hline $\begin{array}{l}\text { 8. Tracked progress in } \\
\text { the attainment of academic } \\
\text { standards. }\end{array}$ & 3.13 & VGE & 3.33 & VGE \\
\hline $\begin{array}{l}\text { 9. Provided } \\
\text { opportunities to respond to } \\
\text { individual needs. }\end{array}$ & 3.25 & VGE & 3.30 & VGE \\
\hline $\begin{array}{l}\text { 10. Promoted self-reflection } \\
\text { and personal accountability for } \\
\text { one's learning. }\end{array}$ & 3.25 & VGE & 3.39 & VGE \\
\hline & 3.34 & VGE & 3.35 & VGE \\
\hline
\end{tabular}

Table 4 presents the perceptions of the respondents on the round robin implementation in terms of the assessment of learning. Similarly with the other two areas abovementioned, both respondents also agree that there has been a positive impact of the scheme on the learning assessment used by the teachers because responses reveal that it was evident to a very great extent. The allowed teachers to determine prior knowledge and have this information at hand to serve as basis 
for collaborative or individual assessment. It was also evident that this scheme allowed teachers to use and employ varied assessment techniques and tools that measures learner achievement in meaningful contexts. This further allowed the transfer of knowledge, understanding and skills to generate desirable outputs.

The results in Table 4 also shows the weighted means of the teacher and student respondents on each of the 10 item questions under the perception of round robin as to assessment. It appears that both teachers and students find that all items in the questionnaire were evident to a very great extent.

The results show that the lowest recorded weighted mean of 3.13 from the teacher's response to item number 8 , indicating that the round robin scheme can track progress in the attainment of academic standards. These results appear to be very near the margin between very great extent and great extent as to their perception on the impact of the round robin scheme to assessment of learning.

The lowest recorded weighted mean from the learners was 3.29 for the first 2 items indicating the variety of techniques and tools used and provided feedback which allows students to reflect on progress. This indicates that the learners perceived that the round robin scheme has least impact on these 2 items of the questionnaire.

On the other hand, the highest weighted mean for both the teachers and learners were 3.50 and 3.46 respectively for the same item indicating that the round robin scheme can use different ways to use learning outcomes.

Overall, there is a positive impact of the implementation of the round robin scheme in teaching science subjects.

For question number 2. What are the reactions of Department Heads and School Heads with the Round Robin Scheme? This question will be answered using the focus group discussion results. The results will highlight the positive and challenged areas of the implementation of the round robin scheme in teaching science in Junior High School.

\section{Positive Highlights}

The implementation of the Round Robin Scheme in teaching science subjects gave positive effects as listed below:

1. The Round Robin scheme is the best strategy to address the content specialization of science teachers.

2. Teacher confidence has not diminished by the shift from discipline-based learning to interdisciplinary approach in learning.

3. Teachers were more focused on the actual teachinglearning process because they were not given advisory classes to handle or manage.

This publication is licensed under Creative Commons Attribution CC BY. http://dx.doi.org/10.29322/IJSRP.11.08.2021.p11656

\section{Challenged Areas Raised}

The implementation of the Round Robin Scheme in teaching science subjects gave rise to the following issues:

1. The difficulty in the preparation of the schedule. This was raised by those schools employing 2 curriculums and have different schedules for each. Some issues on the conflicting schedules of teacher teaching in both curriculums were raised.

2. Advisory classes from the science teachers were given to new and inexperienced advisers which lead to some difficulties arising in the preparation of school forms.

3. Small schools have difficulty complying with the teachers who can teach the specialized subjects in science since these schools have fewer teachers.

4. The grades of learners appear to be not coherent for every quarter when new teachers handle different subjects every quarter.

5. With the quarterly change of teachers, the learners were not able to adjust to the learning situation which may contribute to some undesirable effects to a certain extent.

It appears that the administrators raised pressing issues on the implementation of the round robin scheme in teaching science in Junior High School.

\section{CONCLUSION AND RECOMMENDATION}

Based on the above results, the following are the conclusion noted by the researcher on the implementation of the round robin scheme in teaching science subjects in junior high schools in Pasay City:

1. It has a very positive impact on the content, pedagogy, and assessment of learners

2. The lessons were applied to situations and contexts common to everyday experience.

3. The lessons helped learners construct meaningful learning experiences.

4. Allows use of classroom activities to a very great extent which help learners learn easily.

5. Ensured that learners collaborate and share ideas among each other.

6. Ensured that evaluation takes place in the context of meaningful activities.

7. Allows the use of different ways to evaluate learning outcomes.

The recommendations below are presented in such a way that they are directed to possible implementers who can carry out such recommendation and activity:

A. Administrators 
1. Address the deficiency of teachers in the school as may be allowed under rules.

2. Encourage the collaboration of seasoned advisers with non-seasoned ones.

3. Encourage and provide avenues to teachers for professional development to help augment the deficiency of specialized teachers.

4. Look into the possibility of adapting specific grading standards for assessing science learning achievement.

B. Teachers

1. Continue professional growth even across disciplines to be able to deliver complex lessons with ease.

2. Continue to design more engaging activities to address students' interests and abilities.

3. Design ways on how prior knowledge and skills may be assessed on a quarterly basis.

\section{Researchers}

Future researchers are encouraged to conduct studies on the following areas:

1. Impact of round robin scheme over same respondents over a period of 4 years to be able to compare the achievements on different science areas across curriculum year.

2. Impact of the round robin scheme on the attainment of the science Most Essential Learning Competencies set for by the Department of Education.

3. Impact of the round robin scheme compared to that of the teach all scheme.

\section{APPENDIX}

ANNEX A

PROFILE OF TEACHER RESPONDENTS

\begin{tabular}{|c|c|c|}
\hline \multicolumn{2}{|c|}{ CRITERIA } & \multirow{2}{*}{$\begin{array}{c}\text { NUMBER OF } \\
\text { TEACHERS } \\
7\end{array}$} \\
\hline GENDER & Males & \\
\hline & Females & 23 \\
\hline & Unanswered & 2 \\
\hline \multirow[t]{6}{*}{ AGE } & 60 and above & 2 \\
\hline & $50-59$ & 3 \\
\hline & $40-49$ & 8 \\
\hline & $30-39$ & 9 \\
\hline & $20-29$ & 7 \\
\hline & Unanswered & 2 \\
\hline \multirow[t]{7}{*}{ POSITION } & Teacher I & 10 \\
\hline & Teacher II & 6 \\
\hline & Teacher III & 11 \\
\hline & Master Teacher I & 0 \\
\hline & Master Teacher II & 2 \\
\hline & Unanswered & 3 \\
\hline & Bachelor's Degree & 13 \\
\hline
\end{tabular}

This publication is licensed under Creative Commons Attribution CC BY. http://dx.doi.org/10.29322/IJSRP.11.08.2021.p11656

\begin{tabular}{|l|l|c|}
\hline \multirow{4}{*}{$\begin{array}{l}\text { Highest Educational } \\
\text { Attainment }\end{array}$} & Masteral Units & 15 \\
\cline { 2 - 3 } & Master's Degree & 2 \\
\cline { 2 - 3 } & Doctoral Units & 0 \\
\cline { 2 - 3 } & Doctor's Degree & 0 \\
\cline { 2 - 3 } $\begin{array}{l}\text { Experience (Years in } \\
\text { Service) }\end{array}$ & Unanswered & 2 \\
\cline { 2 - 3 } & $5-10$ & 15 \\
\cline { 2 - 3 } & $11-15$ & 3 \\
\cline { 2 - 3 } & $16-20$ & 1 \\
\cline { 2 - 3 } & $21-25$ & 4 \\
\cline { 2 - 3 } & $26-20$ & 2 \\
\cline { 2 - 3 } & 31 and above & 4 \\
\cline { 2 - 3 } & Unanswered & \\
\hline TOTAL & 32 & \\
\hline
\end{tabular}

ANNEX B

PROFILE OF LEARNER RESPONDENTS

\begin{tabular}{|l|l|c|}
\hline \multicolumn{2}{|c|}{ CRITERIA } & $\begin{array}{c}\text { NUMBER OF } \\
\text { LEARNERS }\end{array}$ \\
\hline \multirow{4}{*}{ GENDER } & Males & 55 \\
\cline { 2 - 3 } & Females & 112 \\
\cline { 2 - 3 } & Unanswered & 4 \\
\hline \multirow{4}{*}{ AGE } & 14 & 1 \\
\cline { 2 - 3 } & 15 & 45 \\
\cline { 2 - 3 } & 16 & 112 \\
\cline { 2 - 3 } & 17 & 9 \\
\cline { 2 - 3 } & 18 & 1 \\
\cline { 2 - 3 } & Unanswered & 3 \\
\hline \multirow{4}{*}{ TOTAL } & 171 & \\
\hline
\end{tabular}

ANNEX C SURVEY QUESTIONNAIRE

The researcher is conducting a study on "Evaluation on the Implementation of Round Robin Scheme in Public Secondary Schools of SDO, Pasay. In this regard, please answer the information below for the successful conduct of the study. Rest assured that your answers will be treated with confidentiality.

The Researcher

DIRECTIONS: Please put a check $(\checkmark)$ in the box/column that corresponds to your answer/information.

Name: (Optional)

School:

wWw.ijsrp.org 
1. Respondents' Profile:

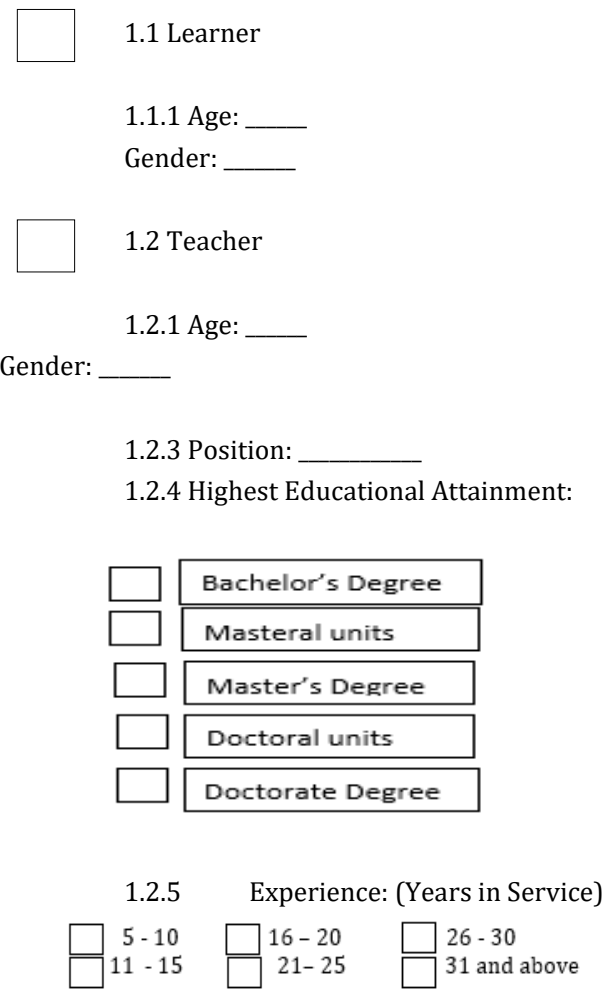

$2 \quad$ Please rate the following indicators using the scale below.

$$
\begin{aligned}
& 4 \text { - Very great extent; } \\
& 3 \text { - Great extent; } \\
& \text { 2-Low extent; } \\
& 1 \text { - Very low extent }
\end{aligned}
$$


ISSN 2250-3153

\begin{tabular}{|c|l|l|l|l|l|}
\hline $5 . \quad \begin{array}{l}\text { Used different ways to evaluate } \\
\text { learning outcomes. }\end{array}$ & & & & \\
\hline 6. & $\begin{array}{l}\text { Determined the existing } \\
\text { knowledge and skills of students. }\end{array}$ & & & & \\
\hline 7. & $\begin{array}{l}\text { Provided information about } \\
\text { difficulties with a concept. }\end{array}$ & & & \\
\hline 8. & $\begin{array}{l}\text { Tracked progress in the } \\
\text { attainment of academic standards. }\end{array}$ & & & & \\
\hline 9. & $\begin{array}{l}\text { Provided opportunities to } \\
\text { respond to individual needs. }\end{array}$ & & & & \\
\hline 10. $\begin{array}{l}\text { Promoted self-reflection and } \\
\text { personal accountability for one's } \\
\text { learning. }\end{array}$ & & & & \\
\hline
\end{tabular}

\section{ANNEX D}

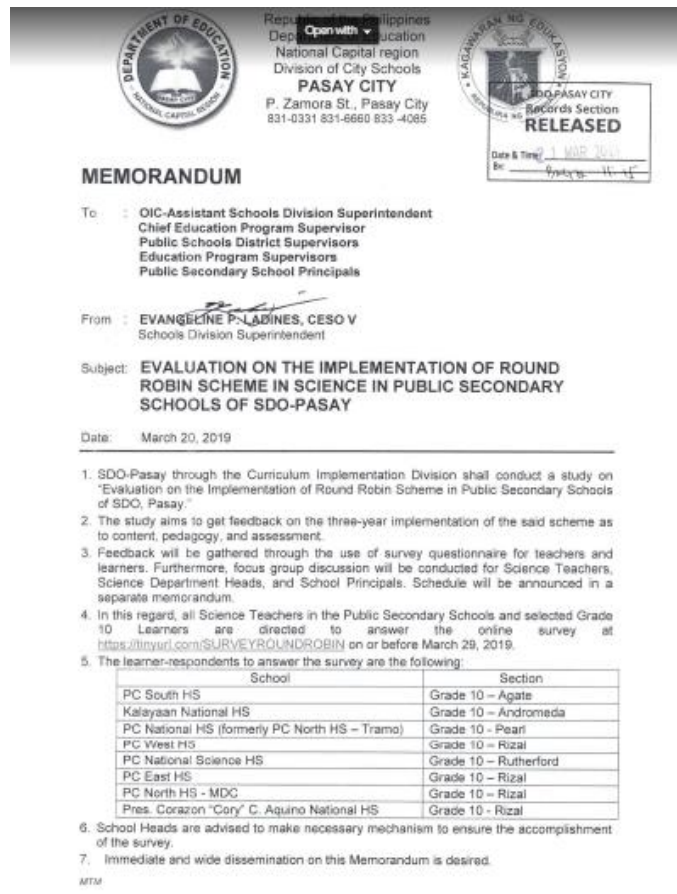

\section{ACKNOWLEDGMENT}

\section{REFERENCES}

3 Science Teaching Standards | National Science Education Standards $\mid$ The National Academies Press. (n.d.). Retrieved August 3, 2021, from https://www.nap.edu/read/4962/chapter/5\#28

Asghar, A., Ellington, R., Rice, E., Johnson, F., \& Prime, G. M. (2012). Supporting STEM Education in Secondary Science Contexts. Interdisciplinary Journal of Problem-Based Learning, 6(2). https://doi.org/10.7771/1541-5015.1349

This publication is licensed under Creative Commons Attribution CC BY. http://dx.doi.org/10.29322/IJSRP.11.08.2021.p11656
Childers, E. A. (n.d.). ScholarWorks Effects of Class Scheduling and Student Achievement on State Testing. Retrieved August 3, 2021, from https://scholarworks.waldenu.edu/dissertations

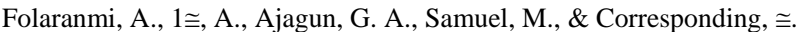
(2019). Effect of Round-Robin Instructional Strategy on Senior Secondary School Students' Interest in Electrochemistry in Federal Capital Territory Abuja Nigeria. Journal of Education and E-Learning Research, 6(3), 129-134.

https://doi.org/10.20448/journal.509.2019.63.129.134

II if ,f SC NM EDUCATION FOR PROBLEMS, ISSUES D DILEMMAS FENAL REPORT OF ME ENTERNATRONAL WORKSHOP ON THE REFORM EN 7rHE TEACE $=$ DENG OF SC EENCE AND TECHNO AT PRIMARY AND SECONDARY LEVEL EN ASA. (2001). www.ibe.unesco.org

Jones, C. (2009). Interdisciplinary Approach-Advantages, Disadvantages, and the Future Benefits of Interdisciplinary Studies. ESSAI, 7, 26. http://dc.cod.edu/essai/vol7/iss $1 / 26$

K to 12 Curriculum Guide SCIENCE. (2016). http://lrmds.deped.gov.ph/.

Learning to Teach Science Out-of-Field: A Spatial-Temporal Experience: Journal of Science Teacher Education: Vol 31, No 7. (n.d.). Retrieved August 3, 2021, from https://www.tandfonline.com/doi/abs/10.1080/1046560X.2020.171831

Luft, J. A., Hanuscin, D., Hobbs, L., \& Törner, G. (2020). Out-of-Field Teaching in Science: An Overlooked Problem. Journal of Science Teacher Education, 31(7), 719-724. https://doi.org/10.1080/1046560X.2020.1814052

Mazzara, E. A. (n.d.). Using the Interdisciplinary Approach to Education to Meet the Literacy Standards in the Common Core: and Ensuring Graduates are College and Career Ready. Retrieved July 30, 2021, from https://digitalcommons.brockport.edu/ehd_theses

Mullis, I. V. S., Martin, M. O., Foy, P., Kelly, D. L., Fishbein, B., \& Pirls, T. \&. (2020). INTERNATIONAL RESULTS IN MATHEMATICS AND SCIENCE TIMSS \& PIRLS.

New research shows how much losing a teacher midyear hurts students Chalkbeat. (n.d.). Retrieved August 4, 2021, from https://www.chalkbeat.org/2018/10/23/21105948/new-research-showsjust-how-much-losing-a-teacher-midyear-hurts-students

Nixon, R. S., Luft, J. A., \& Ross, R. J. (2017). Prevalence and predictors of out-of-field teaching in the first five years. Journal of Research in Science Teaching, 54(9), 1197-1218. https://doi.org/10.1002/TEA.21402

Opara, J. A. (n.d.). INNOVATIVE METHOD OF TEACHING SCIENCE THROUGH INTERDISCIPLINARY APPROACH. 1550-1558. Retrieved July 30, 2021, from www.srjis.com

Orleans, A. V. (2007). The condition of secondary school physics education in the Philippines: Recent developments and remaining challenges for substantive improvements. The Australian Educational Researcher 2007 34:1, 34(1), 33-54. https://doi.org/10.1007/BF03216849

Orleans, A. V. (n.d.). The Condition of Secondary School Physics Education in the Philippines: Recent Developments and Remaining Challenges for Substantive Improvements. 
ISSN 2250-3153

Power of an Interdisciplinary Approach to Science Education \& Research

Teachers of India. (n.d.). Retrieved July 30, 2021, from

http://www.teachersofindia.org/en/article/power-interdisciplinary-

approach-science-education-research

Ramos-Samala, H. de. (2018). Spiral Progression Approach in Teaching Science: A Case Study. KnE Social Sciences, 3(6), 555-567-555-567. https://doi.org/10.18502/KSS.V3I6.2404

SCIENCE FRAMEWORK FOR PHILIPPINE BASIC EDUCATION. (n.d.) Retrieved July 30, 2021, from http://www.sei.dost.gov.ph

Tsybulsky, D., \& Muchnik-Rozanov, Y. (2019). The development of studentteachers' professional identity while team-teaching science classes using a project-based learning approach: A multi-level analysis.

Teaching and Teacher Education, 79, 48-59.

https://doi.org/10.1016/J.TATE.2018.12.006

Tsybulsky, D., \& Muchnik-Rozanov, Y. (2019). The development of studentteachers' professional identity while team-teaching science classes using a project-based learning approach: A multi-level analysis. Teaching and Teacher Education, 79, 48-59. https://doi.org/10.1016/J.TATE.2018.12.006

View of Interdisciplinary Approach-Based Energy Education. (n.d.). Retrieved July 30, 2021, from

https://hipatiapress.com/hpjournals/index.php/remie/article/view/3734/ pdf

You, H. S. (2017). Why Teach Science with an Interdisciplinary Approach: History, Trends, and Conceptual Frameworks. Journal of Education and Learning, 6(4). https://doi.org/10.5539/jel.v6n4p66

AUTHOR

DR. MARIPAZ T. MENDOZA

Education Program Supervisor

Schools Division of Pasay City

Department of Education

Metro Manila, Philippines

maripaz.mendoza001@deped.gov.ph

(0632)09773310982

(0632)09292242915

This publication is licensed under Creative Commons Attribution CC BY. 